園学雑. (J. Japan. Soc. Hort. Sci.) 61(3)：513-520. 1992.

\title{
ブドヴ藤稔’の新梢ならびに果実の 生長に及ぼす各種台木の影響
}

\author{
李 相根・ 久保田尚浩・安井公一 \\ 岡山大学農学部 700 岡山市津島
}

Effects of Different Rootstocks on Shoot Growth, Development of Flower Clusters, and Berry Growth of 'Fujiminori' Grapes

Xiang-Gen Li, Naohiro Kubota and Koichi Yasui

Faculty of Agriculture, Okayama University, Tsushima, Okayama 700

\begin{abstract}
Summary
The objective of this study was to study the effects of different rootstocks on shoot and berry growth of 'Fujiminori' grapes. Budbreak, shoot growth, development of flower clusters, berry growth, and berry quality were investigated in 2-year-old vines grafted on seven different rootstocks: $3309,3306,101-14,5 \mathrm{C}, 8 \mathrm{~B}, \mathrm{SO} \cdot 4$, and $420 \mathrm{~A}$. Vines were grown in plastic containers in an unheated plastic house.

Budbreak began earlier and shoot growth was more vigorous on vines grafted on 3306 , SO-4, and 101-14 compared with those on 420A, 8B, and 5C stocks. The number of lateral shoots and their lengths were smallest on scions grafted on $420 \mathrm{~A}$ stock.

More flower clusters per shoot were formed on vines grafted on $420 \mathrm{~A}, 8 \mathrm{~B}$, and 3306 than were formed on 101-14. Although the number of florets per cluster was not significant among shoots on different rootstocks, the rate of elongation of panicles in vines grafted on both 101-14 and 5C tended to be faster than it was on SO-4 and 420A. No difference was observed in the percentage set of berries among the vines grafted on six stocks except for $420 \mathrm{~A}$, in which the set was significantly higher. Small differences in both flowering time and 'veraison' were observed among the vines grafted on seven stocks. The ratio of seeded berries to total berries was higher in vines grafted on SO-4 and $420 \mathrm{~A}$ stocks than it was vines on $8 \mathrm{~B}$ and 3306 stocks.

The largest berries were observed in vines grafted on 3306, followed by those on 101-14 and 3309 , whereas berries on vines grafted on $5 \mathrm{C}$, SO-4, and $420 \mathrm{~A}$ were smallest. The total soluble solids of the juice were highest in berries harvested from vines on 3309, SO-4, and 3306 stocks. The titratable acidity was relatively low in vines grafted on all stocks, especially that on SO.4. Vines grafted on 3306 stock yielded berries with the highest level of anthocyanin in the skin; the berries from other 'Fujiminori' vines were about equally pigmented.
\end{abstract}

\section{緒 言}

果樹栽培において，台木品種が穂木品種の生育に影 響を及ばすことはよく知られており，ブドウでも樹勢， 結実，収量，果実品質などが台木によって大きく異な る (Huang • Ough, 1989 ; Rives, 1971 ; 植原, 1972, 1984〉。また，穂木品種の生育に及ぼす台木の影響は環

1991 年 12 月 12 日 受理.
境条件や栽培条件によっても異なり，非常に複雑な样 相を呈する．中川（1975）は，台木品種と穂木品種の 組み合わせに関して，“甲州’やデラウェア’では収量の 面からは 101-14，1202, H.F.などが優れ, 品質の面か らは G. M.や3306がよいとしている.また, ‘キャンべ ル・アーリーでは 3306 が収量, 品質ともに優れ, 一方 'マスカット・オブ・アレキサンドリア’では H.F.がよ いとしている. 
ブドウ台木として，これまではフィロキセラ抵抗性 のものが各種用いられてきたが，近年では欧米を中心 にそれらのウイルスフリー化, 新しい台木品種の選抜 と育成，古い台木品種の見直しなどが䅡極的に行われ (Einset Pratt, 1975 ; Howell, 1987 ; Winkler ら, 1974), 日本のブドウ栽培でもウイルスフリー苗が主流 になりつつある。これは，ウイルスに感染したブドウ 樹では樹勢, 収量, 果実品質などが低下することが明 らかにされたことによる(田中，1981，1988；Woodham ら, 1983 ; 山川ら，1982）。しかしながら，これ までブドウ台木の生理生態的特性を調查した報告は少 なく，とくにウイルスフリ一樹についての調查は極め て少ない，また，同じ台木品種でもその特性は報告に よって異なり (Howell, 1987 ; 植原, 1984), 台木の環 境適応性や穂木品種との親和性などについてはなお不 明な点が多い。したがって，近年普及の著しい“巨峰”, “ピオーネ’，“藤稳などのいわゆる4倍体品種と台木品 種との適合性については注とんど明らかにされておら ず，実際栽培での台木品種の選定は栽培者や苗木業者 の経踰にもとづいているのが実状である。

本研究は，ブドウ栽培における好適な台木品種の選 定に資するための基礎資料を得ることを目的として， 7 種類の台木に接いだ藤稔” 2 年生樹の発芽，新梢生 長，花穗発育，結実，果粒の肥大や品質を調查したも のである。

\section{材料および方法}

実験には，リパリアメルペストリス3309（以下 3309), 同 3306, 同 101-14, ベルランディエリ×リパ リア テレキ $5 \mathrm{C}$ (以下 $5 \mathrm{C}$ ), 同 $8 \mathrm{~B}$, ベルランディ工 リメリパリア SO·4（以下 SO-4）および同 $420 \mathrm{~A}$ 台の “藤稔” 2 年樹を用いた。これらは, 台木, 穂木ともすべ て菱頂培養によってウイルスフリー化されたものであ る. 1990 年 3 月 24 日に 3 芽を残してせん定した後, 壤 土：マサ土：堆肥が $6: 3: 1$ の培土で容積約 50 literのコンテナに植之, プラスチックハウスに搬入し た。なお，植えかえ前の 2 月下旬に化成肥料 (N：P： $\mathrm{K}=8: 8: 8$ ) を各個体 $15 \mathrm{~g}$ 施与した。

各台樹 5 個体を供試し, 発芽の調查後は各個体に生 育のよい新梢を1本だけ残し，花穂も1房に制限した。 なお，芽かきで除去したすべての新梢について花穗数 を調査した。各台樹について平均的な新梢および花穂 をつけた 3 個体を選び, 新梢長と花穗長を経時的に測 定した，本梢については 18 節位葉の展開時に摘心し， 副梢については 2 葉で摘心した後，1葉摘心を繰り返
した。開花期に新梢の基部径，ならびに副梢の発生数， およびその長さと葉数を調查した，開花直前に花穂当 たりの小花数を調查した後, 先端約 $10 \mathrm{~cm}$ を残して切 り込んだ. 開花約 2 週間後に着粒数を調查した後， 1 果房約 30 粒に制限し,このうちから平均的な 5 果粒を 選び，収模時まで経時的に横径と縦径を測定した。な お，摘粒果については収穫果粒とともに種子数を調查 した。

8 月 16 日に全果房を収穫し,果房重と果粒数を調查 した後, 各果房 10 果粒について重さ, 横径と縦径, お よび糖含量（屈折計示度）を測定した。また，2重が 一ゼで摧汁後, 酸含量 $(0.1 \mathrm{~N}-\mathrm{NaOH}$ で滴定後酒石酸 換算）を測定した。果皮のアントシアニン含量は，直 径 $10 \mathrm{~mm}$ の果皮ディスク 5 枚に $1 \%$ 塩酸メタノール を加之, 冷蔵庫内で 12 時間抽出した後, $530 \mathrm{~nm}$ の吸光 度を湘定することにより求めた。

\section{結 果}

発芽の開始は SO·4, 3306 および101-14の各台樹で 最も早く, $420 \mathrm{~A}$ 台樹ではこれよりも4 日遅れた. 前者 では発芽の揃いも優れ，発芽終了は後者よりも8日早 かった(第1図)。

新梢伸長の結果も発芽の場合とほぼ同様で, 3306 台 樹や SO· 4 台樹に比べて $8 \mathrm{~B}, 420 \mathrm{~A}, 5 \mathrm{C}$ などの台樹で 劣り，とくに $8 \mathrm{~B}$ 台樹の伸長が著しく劣った(第 2 図). 3306 台樹では葉数もやや多かったが, 台樹間での 差は小さかった(デー夕省略).

開花期における新梢基部の太さは $420 \mathrm{~A}$ 台樹で著し く小さかったが、これ以外では台樹間に差がなかった。 副梢の発生数は 101-14，5C，3306などの台樹で多く， 420A台樹で少なかったが, その生長は8 B台樹や10114 台樹で旺盛であった (第 1 表).

新梢当たりの花穂数は $420 \mathrm{~A}$ 台樹が最も多く, $8 \mathrm{~B}$, 3306 などの台樹がこれに次ぎ, 101-14 台樹では有意に 少なかった。花穂の生長は 101-14 台樹と $5 \mathrm{C}$ 台樹で優 れ, SO·4と $420 \mathrm{~A} の$ 両台樹で劣ったが, 花穂当たりの 小花数には台樹間に差がなかった。結実率は $420 \mathrm{~A}$ 台 樹で著しく高いほかは差がなかった，101-14台樹と 3306 台樹では $420 \mathrm{~A}$ 台樹や $8 \mathrm{~B}$ 台樹よりも開花が 3 〜 4 日早く, また開花期の果梗径は $420 \mathrm{~A}$ 台樹で有意 に細かった（第 2 表，第 3 図).

摘粒果と収穫果の全果粒について種子数をみたとこ 万(第 3 表), 有核果率は SO 4 台樹が $100 \%$ で最も高 く, 次いで $420 \mathrm{~A}, 5 \mathrm{C}, 3309$ などの台樹も $90 \%$ 以上で あったのに対し, 8 B 台樹では $48.4 \%$ と著しく低かっ 


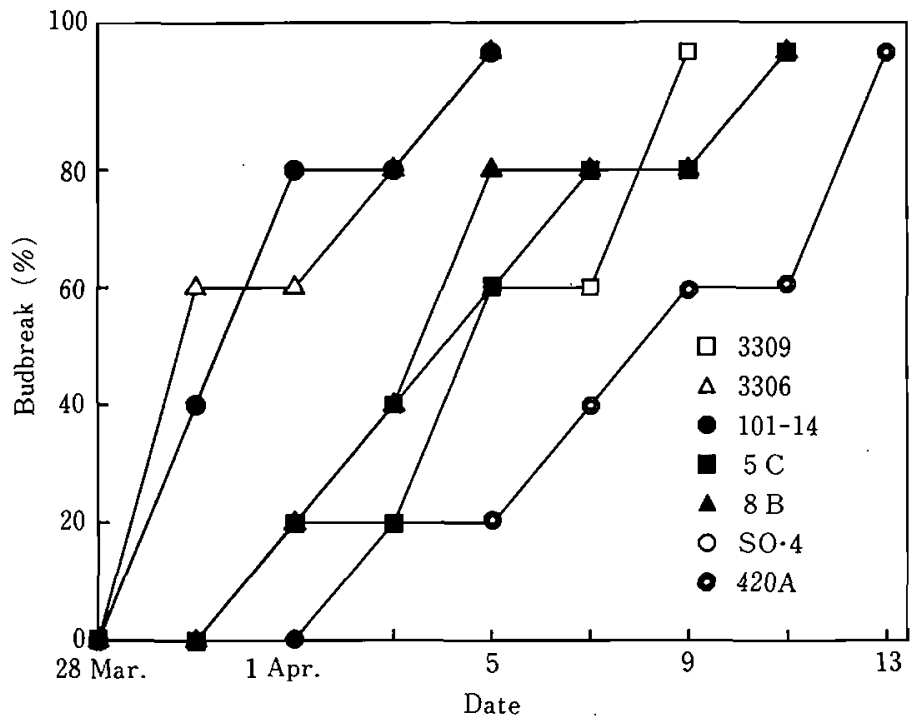

Fig. 1. Effect of different rootstocks on the time of budbreak of 'Fujiminori' vines grown in plastic containers. A cane on each vine was pruned to 3-node. Note that the line for SO.4 stock coincided with that for 101-14 stock.

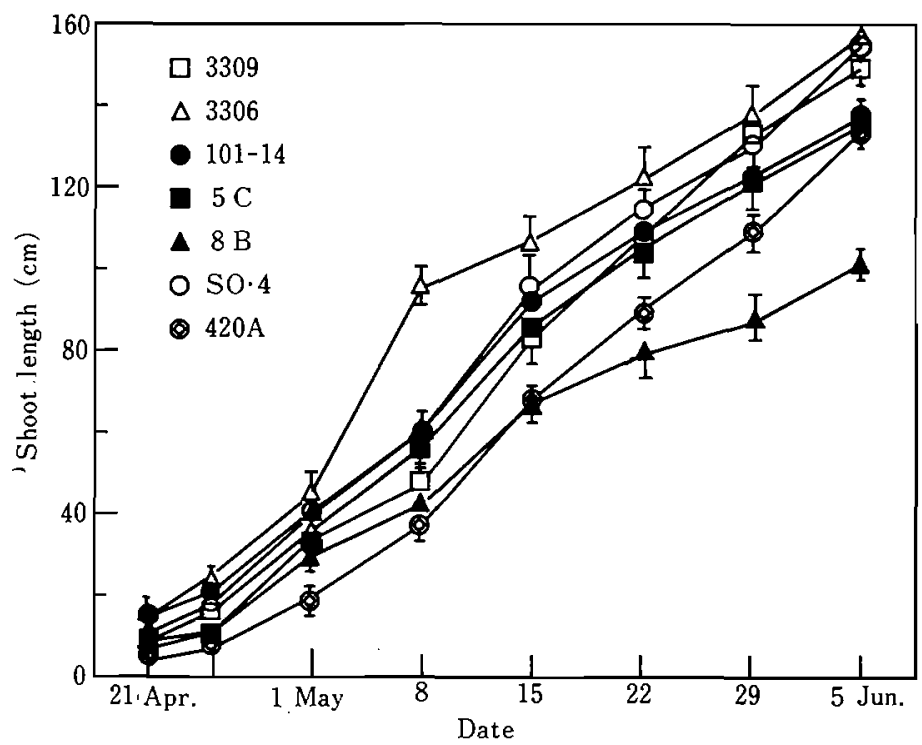

Fig. 2. Shoot growth curves of 'Fujiminori' vines on different rootstocks. Only one shoot per vine was allowed to grow. Vertical bars are the standard error. $n=3$.

た。これを種子数別の割合でみると， 1 果粒に 2 個以 上の種子を含む果粒の割合は, 有核果率の低い3306 と $8 \mathrm{~B}$ の再台樹で低かった，有核果粒中の平均種子数は， $5 \mathrm{C}, 8 \mathrm{~B}$ および $420 \mathrm{~A} の$ 各台樹で多く,3306，101-14，
$\mathrm{SO} \cdot 4$ などの台樹で少なかった.

果粒肥大は，横径では 3306 台樹や $8 \mathrm{~B}$ 台樹で優れ (第 4 図)，一方縦径では 101-14，3309 および3306の 各台樹で優れた（デー夕省略）。420A 台樹の果粒肥大 
Table 1. Effect of different rootstocks on shoot growth of 'Fujiminori' vines grown in plastic container ${ }^{2}$.

\begin{tabular}{lcccc}
\hline \hline Rootstocks & $\begin{array}{c}\text { Stem diameter } \\
\text { above graft } \\
\text { union (mm) }\end{array}$ & $\begin{array}{c}\text { No. of shoots } \\
\text { per vine }\end{array}$ & $\begin{array}{c}\text { Total length } \\
\text { of shoot per } \\
\text { vine }(\mathrm{cm})\end{array}$ & $\begin{array}{c}\text { Total no. of } \\
\text { leaves per vine }\end{array}$ \\
\hline 3309 & $12.6 \mathrm{a}^{y}$ & $7.6 \mathrm{bc}^{\mathrm{x}}$ & $59.0 \mathrm{ab}^{\mathrm{x}}$ & $16.0 \mathrm{~b}^{\mathrm{x}}$ \\
3306 & $14.5 \mathrm{a}$ & $8.3 \mathrm{ab}$ & $60.0 \mathrm{ab}$ & $18.0 \mathrm{ab}$ \\
$101-14$ & $14.1 \mathrm{a}$ & $9.3 \mathrm{a}$ & $82.7 \mathrm{a}$ & $22.0 \mathrm{a}$ \\
$5 \mathrm{C}$ & $13.3 \mathrm{a}$ & $8.6 \mathrm{ab}$ & $67.0 \mathrm{ab}$ & $17.7 \mathrm{ab}$ \\
$8 \mathrm{~B}$ & $13.5 \mathrm{a}$ & $7.6 \mathrm{bc}$ & $88.7 \mathrm{a}$ & $22.0 \mathrm{a}$ \\
SO-4 & $14.0 \mathrm{a}$ & $7.6 \mathrm{bc}$ & $74.0 \mathrm{a}$ & $21.0 \mathrm{ab}$ \\
$420 \mathrm{~A}$ & $10.5 \mathrm{~b}$ & $6.3 \mathrm{c}$ & $34.3 \mathrm{~b}$ & $9.3 \mathrm{c}$ \\
\hline
\end{tabular}

${ }^{z}$ Measured at the flowering stage.

y Average values were analysed with Duncan's multiple range test.

Values within columns followed by the same letter are not significantly different at $P=0.01$.

$x$ Values within columns followed by the same letter are not significantly different at $\mathrm{P}=0.05$.

Table 2. Effect of different rootstocks on the number and development of flower clusters, and the berry setting in 'Fujiminori' vines.

\begin{tabular}{lcccccc}
\hline \hline Rootstocks & $\begin{array}{c}\text { Diameter of } \\
\text { peduncle (mm) }\end{array}$ & $\begin{array}{c}\text { No. of flower } \\
\text { clusters per vine }\end{array}$ & $\begin{array}{c}\text { No. of florets } \\
\text { per cluster }\end{array}$ & $\begin{array}{c}\text { No. of berries set } \\
\text { per cluster }\end{array}$ & Set (\%) & Bloom date \\
\hline 3309 & $4.7 \mathrm{a}^{\mathrm{z}}$ & $0.94 \mathrm{ab}$ & $187.0 \mathrm{a}$ & $60.7 \mathrm{a}$ & $29.1 \mathrm{~b}$ & $27 \mathrm{May}$ \\
3306 & $5.5 \mathrm{a}$ & $0.96 \mathrm{ab}$ & $187.7 \mathrm{a}$ & $56.3 \mathrm{a}$ & $30.6 \mathrm{~b}$ & $26 \mathrm{May}$ \\
$101-14$ & $5.6 \mathrm{a}$ & $0.60 \mathrm{c}$ & $296.3 \mathrm{a}$ & $46.0 \mathrm{a}$ & $22.7 \mathrm{~b}$ & $25 \mathrm{May}$ \\
$5 \mathrm{C}$ & $4.8 \mathrm{a}$ & $0.86 \mathrm{bc}$ & $297.3 \mathrm{a}$ & $48.7 \mathrm{a}$ & $20.6 \mathrm{~b}$ & $28 \mathrm{May}$ \\
$8 \mathrm{~B}$ & $5.0 \mathrm{a}$ & $0.96 \mathrm{ab}$ & $292.7 \mathrm{a}$ & $54.0 \mathrm{a}$ & $28.6 \mathrm{~b}$ & $29 \mathrm{May}$ \\
$\mathrm{SO} \cdot 4$ & $4.8 \mathrm{a}$ & $0.86 \mathrm{bc}$ & $145.0 \mathrm{a}$ & $39.0 \mathrm{a}$ & $32.8 \mathrm{~b}$ & $27 \mathrm{May}$ \\
$420 \mathrm{~A}$ & $3.8 \mathrm{~b}$ & $1.30 \mathrm{a}$ & $154.7 \mathrm{a}$ & $52.0 \mathrm{a}$ & $57.2 \mathrm{a}$ & $29 \mathrm{May}$ \\
\hline
\end{tabular}

${ }^{z}$ Values within columns followed by the same letter are ont significantly different at $\mathrm{P}=0.05$.

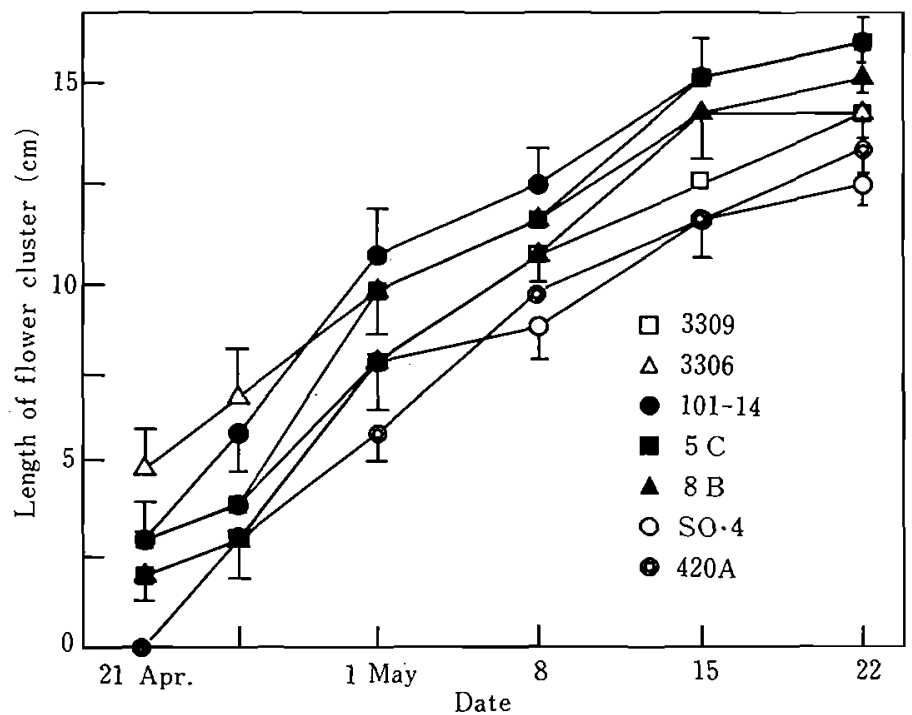

Fig. 3. Developmental curves of flower clusters of 'Fujiminori' vines on different rootstocks. Flower clusters were reduced to one per shoot. Vertical bars are the standard error. $n=3$. 
園学雑. (J. Japan. Soc. Hort. Sci.) 61 (3)：513-520. 1992.

Table 3. Effect of different rootstocks on the seed development of 'Fujiminori' vines.

\begin{tabular}{|c|c|c|c|c|c|c|c|}
\hline \multirow{2}{*}{ Rootstocks } & \multicolumn{5}{|c|}{ Percentage of berries based on number of seeds } & \multirow{2}{*}{$\begin{array}{l}\text { Percentage of } \\
\text { seeded berries }\end{array}$} & \multirow{2}{*}{$\begin{array}{l}\text { No. of seeds } \\
\text { per seeded berry }\end{array}$} \\
\hline & 0 & 1 & 2 & 3 & 4 & & \\
\hline 3309 & 8.5 & 62.3 & 25.4 & 3.8 & 0 & $91.5 \mathrm{a}^{z}$ & $1.4 \mathrm{~b}^{\mathrm{y}}$ \\
\hline 3306 & 37.6 & 48,4 & 11.7 & 1.8 & 0.5 & $62.4 \mathrm{~b}$ & $1.3 \mathrm{~b}$ \\
\hline $101-14$ & 25.9 & 50.2 & 22.8 & 1.1 & 0 & $74.1 \mathrm{~b}$ & $1.3 \mathrm{~b}$ \\
\hline $5 C$ & 7.0 & 56.6 & 23.5 & 8.8 & 4.1 & $93.0 \mathrm{a}$ & $1.6 \mathrm{a}$ \\
\hline $8 B$ & 51.6 & 29.3 & 13.9 & 2.2 & 3.0 & $48.4 \mathrm{c}$ & $1.6 \mathrm{a}$ \\
\hline $\mathrm{SO} \cdot 4$ & 0 & 76.1 & 19.5 & 4.4 & 0 & $100.0 \mathrm{a}$ & $1.3 \mathrm{~b}$ \\
\hline $420 \mathrm{~A}$ & 2.3 & 58.4 & 25.1 & 13.6 & 0.6 & $97.7 \mathrm{a}$ & $1.6 \mathrm{a}$ \\
\hline
\end{tabular}

${ }^{2}$ Values within columns followed by the same letter are not significantly different at $P=0.01$.

$y$ Values within columns followed by the same letter are not significantly different at $P=0.05$.

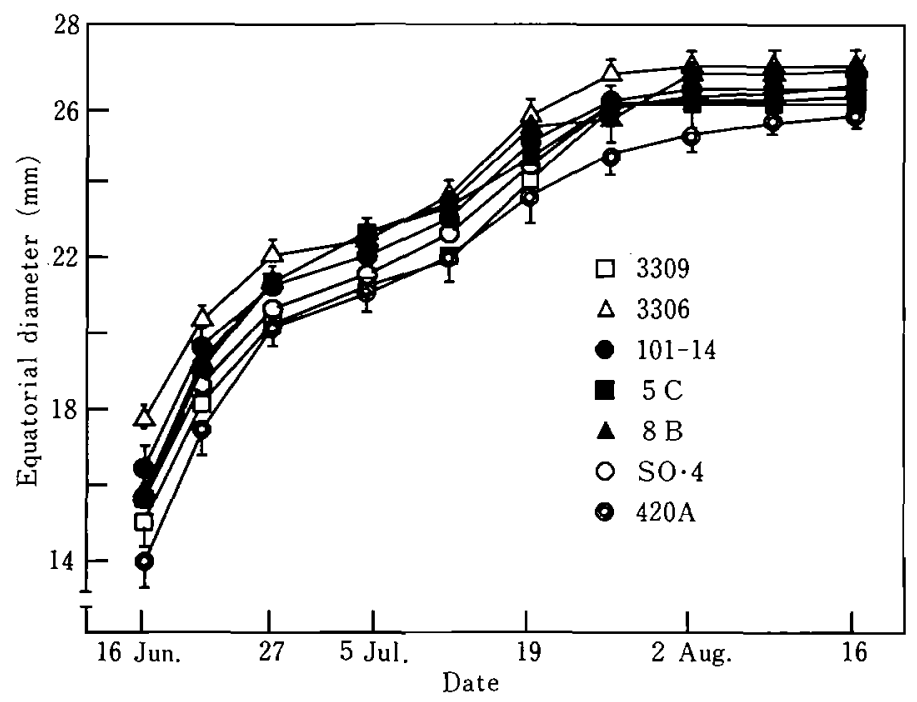

Fig. 4. Growth curves of 'Fujiminori' berries on vines grafted to different rootstocks. Vertical bars are the standard error. $n=15$.

は横径, 粎径ともに最も小さかった。収穕時の果粒径 もこれとほぼ同様の結果であった（第 4 表).

成熟の開始は 3309 台樹が他の台樹よりも 3 - 5 日 遅れた。果房重は 3306 台樹で最も優れ, 次いで 3309 , $420 \mathrm{~A}$ などの台樹で大きく，一方 $8 \mathrm{~B}$ 台樹では著しく 小さかった。果粒重は 3306 台樹が $14.2 \mathrm{~g}$ と最も優れ, 101-14と3309の両台樹がこれに次いだ。一方, 5C台 樹と $\mathrm{SO} \cdot 4$ 台樹の果粒は著しく小さく，各々 $10.7 \mathrm{~g}$ と $11.5 \mathrm{~g}$ であった。果形比は 3306 と $5 \mathrm{C}$ の両台樹でかず かに小さかったが, 有意な差ではなかった. 果汁の屈 折計示度は $3309, \mathrm{SO} \cdot 4,3306$ などの台樹が 17.7 以上 であったのに対し，101-14 台樹では 16.8 とやや低か
った，酸含量はSO·4や 3309 の台樹よりも 101-14 台 樹で多かったものの，全般にいずれの台樹とも少なか った。果皮のアントシアニン含量は 3306 台樹で著しく 多く，これ以外では台樹間に差がなかった（第 4 表）.

\section{考察}

ブドウ樹の生育や収量, 果実品質などに台木品種が 密接に関係するとされている（中川，1975；植原, 1984）が，これを具体的に裹付けるデ一夕は比較的少 ない。とくに，日本で急速に栽培面穔が增加している “巨峰”を始めとした 4 倍体品種ではこの種の研究が極 めて少なく、これら品種における台木の選定は栽培者 や苗木業者の経験にもとづいていることが多い. 本実 
Table 4. Effect of different rootstocks on berry size, total soluble solids and titratable acidity of the juice, and anthocyanin content of skin at harvest in 'Fujiminori' vines'.

\begin{tabular}{|c|c|c|c|c|c|c|c|c|c|c|}
\hline \multirow{2}{*}{ Rootstocks } & \multirow{2}{*}{ Veraison } & \multirow{2}{*}{$\begin{array}{l}\text { Cluster } \\
\text { weight } \\
\text { (g) }\end{array}$} & \multirow{2}{*}{$\begin{array}{l}\text { No. of } \\
\text { berries per } \\
\text { cluster }\end{array}$} & \multirow{2}{*}{$\begin{array}{c}\text { Berry } \\
\text { weight } \\
\text { (g) }\end{array}$} & \multicolumn{2}{|c|}{ Berry size (mm) } & \multirow{2}{*}{$\begin{array}{l}\text { Length/ } \\
\text { width } \\
\text { ratio }\end{array}$} & \multirow{2}{*}{$\begin{array}{l}\text { Total solu- } \\
\text { ble solids } \\
\left(^{\circ} \mathrm{Brix}\right)\end{array}$} & \multirow{2}{*}{$\begin{array}{c}\text { Titratable } \\
\text { acidity } \\
\text { (mg/100 ml) }\end{array}$} & \multirow{2}{*}{$\begin{array}{l}\text { Anthocyanin } \\
\text { content (O.D. } \\
\text { at } 530 \mathrm{~nm})\end{array}$} \\
\hline & & & & & Length & Width & & & & \\
\hline 3309 & 15 July & $346.0 \mathrm{~b}^{y}$ & $31.0 a^{x}$ & $12.6 b c^{x}$ & $30.0 \mathrm{ab}^{x}$ & $26.3 b^{x}$ & $1.14 \mathrm{a}^{\mathrm{x}}$ & $18.1 \mathrm{a}^{\mathrm{x}}$ & $195.1 b c^{y}$ & $0.589 b^{x}$ \\
\hline 3306 & 10 July & $428.5 \mathrm{a}$ & $32.7 \mathrm{a}$ & $14.2 \mathrm{a}$ & $30.6 \mathrm{a}$ & $27.7 \mathrm{a}$ & $1.10 \mathrm{a}$ & $17.7 \mathrm{abc}$ & $213.6 \mathrm{ab}$ & $1.074 \mathrm{a}$ \\
\hline $101-14$ & 12 July & $287.2 \mathrm{bc}$ & $22.7 \mathrm{a}$ & $13.0 \mathrm{~b}$ & $30.5 \mathrm{ab}$ & $26.2 \mathrm{~b}$ & $1.16 \mathrm{a}$ & $16.8 \mathrm{~d}$ & $234.3 \mathrm{a}$ & $0.541 \mathrm{~b}$ \\
\hline $5 \mathrm{C}$ & 11 July & $302.2 \mathrm{bc}$ & $30.3 \mathrm{a}$ & $10.7 \mathrm{e}$ & $27.7 \mathrm{~d}$ & $25.1 \mathrm{c}$ & $1.10 \mathrm{a}$ & $17.1 \mathrm{~cd}$ & $213.6 \mathrm{ab}$ & $0.617 \mathrm{~b}$ \\
\hline $8 \mathrm{~B}$ & 12 July & $259.7 \mathrm{c}$ & $26.0 \mathrm{a}$ & $12.4 \mathrm{bcd}$ & $29.4 \mathrm{~b}$ & $26.4 \mathrm{~b}$ & $1.11 \mathrm{a}$ & $17.4 \mathrm{bcd}$ & $197.3 \mathrm{bc}$ & $0.631 \mathrm{~b}$ \\
\hline $\mathrm{SO}-4$ & 10 July & $317.6 \mathrm{~b}$ & $29.0 \mathrm{a}$ & $11.5 \mathrm{de}$ & $28.6 \mathrm{c}$ & $25.8 \mathrm{~b}$ & $1.11 \mathrm{a}$ & $17.8 \mathrm{ab}$ & $185.5 \mathrm{c}$ & $0.545 \mathrm{~b}$ \\
\hline $420 \mathrm{~A}$ & 11 July & $342.1 \mathrm{~b}$ & $30.0 \mathrm{a}$ & $12.0 \mathrm{~cd}$ & $29.9 \mathrm{ab}$ & $25.8 \mathrm{~b}$ & $1.16 \mathrm{a}$ & $17.6 \mathrm{bcd}$ & $214.7 \mathrm{ab}$ & $0.680 \mathrm{~b}$ \\
\hline
\end{tabular}

All fruit clusters were harvested on 16 August.

$y$ Values within columns followed by the same letter are not significantly different at $P=0.01$.

$\times$ Values within columns followed by the same letter are not significantly different at $P=0.05$.

験では，4倍体ブドウのなかでも比較的新しい品種で ある藤稔について，その生育，結実，果粒の肥大や品 質などの台木種類間での違いを検討した。

\section{発芽と新梢生長}

本実験において, '藤稔’の発芽や新梢生長は, 3306 と $\mathrm{SO} \cdot 4$ の両台樹で優れ，420A，8 B，5Cなどの台樹で 劣った.すなわち, 3306 台樹や $\mathrm{SO} \cdot 4$ 台樹では $420 \mathrm{~A}$ や $8 \mathrm{~B}$ などの台樹に比べて発芽が早く, 新梢生長も旺盛 であった，台木品種によって樹体の生育にこのような 差が生じた原因については明らかでないが，その一因 として台木種類間での養分吸収力の違いが考えられる。 尾形ら（1989）は，モモ台木の無機盖分の吸収に関し て, 葉中の $\mathrm{P}, \mathrm{Ca}, \mathrm{Mg}$ 含量はユスラウメやニワウメ などの矮性台よりもやセイモモ台で多いことを報告し ている。しかし，本実験において，副梢の生長は新梢 伸長の劣った $8 \mathrm{~B}$ 台樹で著しく旺盛であった。したが って，樹体の生育に及ばす台木の影響については，無 機盖分の吸収を始めとして根の生長速度や生長パタ一 ン，根量などと関連させて検討する必要がある。

本実験で供試した藤稔’の新梢生長は“巨峰に比べて やや弱いとされ（石川・川上，1990）また穂木品種の 生育が台木によって異なることはよく知られている. 穂木品種の生育に関して, Howell (1987) は, 本実験 で供試した台木品種のなかでは SO-4，3309，3306, $5 \mathrm{C}, 8 \mathrm{~B}$ などで強く，101-14 と 420A で最も弱いとし ている。一方，植原(1984)は，台負けに関して，3309 や420A が中程度で，3306 および 101-14がこれに次 ぎ，420A，SO-4，5C，8Bなどが弱いとしている. 穂 木品種の生育に及ぼす台木の影響と台負けの程度とは 必ずしも同質のものではないが，新梢生長が $\mathrm{SO} \cdot 4$ や
3306 などの台樹で優れ，420A 台樹で少った本実験の 結果は Howell（1987）の説に類似した。

\section{花穗の発達と結実}

本実験において, ‘藤稔’の着房数はいずれの台樹とも 少なく, 新梢当たり 1 個以上の花穂を着けた台樹は $420 \mathrm{~A}$ だけであった，1樹当たりの着房数もほぼ同様 で, 420A 台樹で最も多く, SO·4 と 101-14の雨台樹で 少なかった。

石川・川上（1990）は，5BBと3309台の“巨峰”よ び藤稔の 1 樹当たりの着房数は 3309 台樹では而品種 に差がないが，5BB 台樹では‘巨峰よりも藤稔で多い ことを報告している.品種登録後の歴史が短い藤稔に

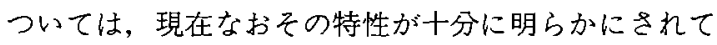
いるとはいえないが，本実験において花穂数が少なか ったのは 1 年目を植木錸で生育させたことが関係して いるかも知れない。

花穂の生長は 101-14 と 5Cの両台樹で優れ, SO・4 と $420 \mathrm{~A}$ の両台樹で劣った，花穂当たりの小花数も前 者で多かったが，多くの台樹において個体間に変動が みられ，台樹間での有意な差は認められなかった。ま た，結実率は $420 \mathrm{~A}$ 台樹で著しく高く、これ以外では台 樹間に差がなかった。 $420 \mathrm{~A}$ 台樹では副梢の発生数が 少なく，またその生長も他の台樹に比べて小きかった ことから、このことが $420 \mathrm{~A}$ 台樹の高い結実率をもた らしたと思われる，新梢が強势であると結実率が低下 しやすいことはよく知られている(岡本ら，1980)。ま た，岡本ら（1984）は“巨峰”を含む6 品種の 4 倍体ブド ウの結実率をみたところ,いずれも 21.7 35.8\%の範 团であった。これらの結果と比へてて,藤稔”の結実率は 上述の $420 \mathrm{~A}$ 台樹を除いては, 他の巨峰群品種とほば 
同様であったことから，結実に及ばす台木の影響は小 さいと思われる.

藤稔は 4 倍体ブドウのなかでは無核果の混入が最 も少ない部類に属するといわれているが，結寒したす べての果粒について種子数をみたところ, 有核果率は 台木によって著しく異なった。すなわち, SO・4 台樹で は全果粒が有核果であり，次いで $420 \mathrm{~A} ， 5 \mathrm{C}, 3309$ な どの台樹も $90 \%$ 以上が有核果であったが，これ以外の 台樹，とくに $8 \mathrm{~B}$ 台樹では $48.4 \%$ と著しく低かった. これらの数值は, ‘紅富士’, ‘紅伊豆', ‘八ニーレッド'な どについてのこれまでの報告（岡本ら 1984）と類似し た。台林によるこのような違いが何に起因するのかは 明らかでないが，岡本ら（1984）は‘巨峰や゙ピオーネ’ で有核果が少ないのは胚珠の発達が不十分なことに加 えて，花粉管の子房内での生長が不活発なために胚珠 が不受精になりやすいことによるとしている．本実験 において有核果の平均種子数に台樹間差がみられたが， このことと有核果率の台樹間差との間には明確な関係 は認められなかった。岡本ら（1984）もブドウの有核 果率と種子数との間には関係がないとしている。

\section{果粒の肥大と品質}

石川・川上（1990）は，“藤稔’の果粒肥大は‘巨峰’よ りも著しく優れ，また 3309 台樹よりも5BB 台樹で多 いことを報告している．本実験においても，果粒肥大 は台木によって著しく異なり，3306 台樹で最も優れ， 101-14や3309などの台樹がこれに次ぎ，5C と SO-4 の両台樹で劣った。一般に, ブドウ果粒の大きさは種 子数に比例し, 種子数が多いほど棵粒が大きいとされ ている(中川，1978)。しかしながら，本実験では種子 数の最も少ない3306 台樹の果粒が最も大きかった。本 実験では葉面種や葉の機能に関する調查を行っていな いが，これらが果粒の肥大に関係していることはよく 知られており，今後葉面稓，葉の構造や生理機能など の面からの解析が必要である. $5 \mathrm{BB}$ と 3309 を台木と した“藤稔”, ‘巨峰”ともに, 果汁の糖度および酸含量に は台樹間に差がないことが明らかにされている（石 川・川上，1990)。本実験において，屈折計示度は 16.8 18.1の範囲にあったが, 台樹間で有意差がみら れ，3309 台樹で有意に高く，101-14 台樹で最も低かっ た. 酸含量も台樹によって異なったが, 全般に各台樹 とも少なかった，本実験では，“ピオーネ’の収穫指標よ りもやや早い成熟開始後 30－35 日目に果房を収穫し たが,酸含量からみで藤稔ではこれよりもやや早く収 穫する必要があると思われた。成整の開始は 3309 台樹
でやや遅れた以外は台樹間に顕著な差がなく，植原 （1972，1984）の報告とほぼ一致した。

本実験において,果皮の着色は 3306 台樹で著しく優 れ，これ以外では台樹間に差がなかった３306台樹 は，上に述べたように新梢や果粒の生長が最も優れ， また果粒当たりの平均種子数も少なかったが，このこ とが着色にどのように関係したかについては更に検討 する必要がある。石川・川上（1990）は，5BBと 3309 台では“藤稔’の着色に差が認められないことを報告し ているが, ブドウ果粒の着色が台木間や樹体間で大き く異なることはよく知られている(中川，1975；小野 ら, 1987 ; 植原, 1984).

以上の結果を絵合して考えると，本実験で供試した 台木品種の範囲内では, “藤稔”適した台木は果実品質 の点からみて $3306 や 3309$ と思われた。しかしながら， 本実験はコンテナ植之樹について行われたものであり， 生産樹でも同様な結果が得られるか否かについては, 台木によってこのような違いが生じた背景とともに， 今後の検討が必要である。

\section{摘要}

ブドウ栽培における好適な台木品種の選定に瓷する ための基礎資料を得ることを目的として，3309，3306， 101-14，5C，8 B，SO·4 および 420Aの計 7 種類の台 木に接いだコンテナ植え“藤稔” 2 年生樹を供試し, 発 芽, 新梢生長, 着穂性, 結実性, 果粒の肥大や品質な どを調查した。

発芽と新梢生長は $3306, \mathrm{SO} \cdot 4,101-14$ などの台樹で 優れ，420A，8 B および $5 \mathrm{C}$ 各台樹で劣った， $420 \mathrm{~A}$ 台樹では副梢の生長も著しく小きかった。

新梢当たりの花穂数は $420 \mathrm{~A} ， 8 \mathrm{~B} ， 3306$ などの台樹 で多く，101-14台樹で少なかった。花穂の伸長は10114 と $5 \mathrm{C}$ の両台樹で優れ, SO・4 台樹と $420 \mathrm{~A}$ 台樹で 劣ったが，小花数には台樹間に差がなかった，結実率 は 420A 台樹で著しく高いほかは台樹間に差がなかっ た。開花期や成熟開始期の台樹間差は小さかった。有 核果率は $\mathrm{SO} \cdot 4,420 \mathrm{~A}$ などの台樹で高く， $8 \mathrm{~B}$ 台樹で 著しく低かった，有核果粒の平均種子数は $420 \mathrm{~A}, 8 \mathrm{~B}$ などの台樹で多く, 3306, SO·4 などの台樹で少なかっ た。

果粒は 3306 台樹で最も大きく，次いで101-14 と 3309 の両台樹で優れ，5 C, SO・4，420A な゙の台樹 で劣った，果汁の糖含量は $3309, \mathrm{SO} \cdot 4,3306$ などの 台樹で多く，101-14 台樹で少なかった. 酸含量は各台 樹とも少なく，とくに $\mathrm{SO} \cdot 4$ 台樹で少なかった，果皮 
のアントシアニン含量は 3306 台樹で著しく多いはか は台樹間に差がなかった。

謝辞 本研究の実施に際して多大の御援助を下 さった(株)山陽農園社長 大森豊徳氏に感謝の意を表 する。

\section{引用文献}

Einset, J. and C. Pratt. 1975. Grapes. p. 130-153. In: J. Janick and J. N. Moore (eds.). Advances in fruit breeding. Purdue Univ. Press, West Lafayette, Ind.

Howell, G. S. 1987. Vitis rootstocks. p. 451-472. In: C. Rom and R. F. Carlson (eds.). Rootstocks for fruit crops. John Wiley \& Sons, New York.

Huang, Z. and C. S. Ough. 1989. Effect of vineyard locations, varieties, and rootstocks on the juice amino acid composition of several cultivars. Amer. J. Enol. Viticult. $40: 135-139$.

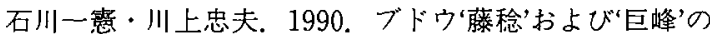
生育および品質の比較. 園学雑. 59 (別 2)：192193.

中川昌一. 1975. ブドウ(第 6 章). p. 350-407. 小林 章・ 苫名 孝共編。果樹生産ハンドブック，養賢堂。東 京.

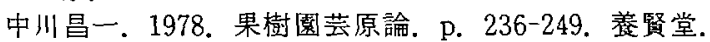
東京.

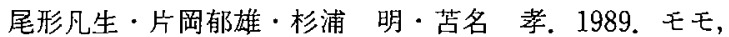
ネクタリン及びスモモの無機荃分吸収に及ぼす各種

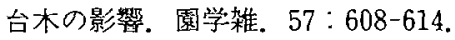

岡本五郎・渡辺好昭・島村和夫. 1980. ブドウ，巨峰の強 势な新梢に对する開花前の摘心及び B- 9 撒布が花 穂の栄坫と結実に及ぼす影響。岡山大農学報。56： $1-10$.

网本五郎・山本恭子・島村和夫. 1984. ‘巨峰’を含む数種 の4倍体ブドウにおける無核果混入の品種間差異に 関する研究. 園学雑. 53 : 251-258.

小野俊朗・依田征四・高木伸友. 1987。ブドウ・ピオーネ’ の果実糖度の上昇過程と果皮色との関係。園学要旨。 昭 62 秋：108-109.

Rives, M. 1971. Statistical analysis of rootstock experiments as providing a definition of the terms 'vigor'and 'affinity' in grapes. Vitis $9: 280-290$.

田中宽康。1981. ブドウ'巨峰’の赤熟れ現象。今月の宸薬 25 ( I) : 42-45.

田中寛康. 1988. わが国におけるブドウ台木のウイルス保 毒状況，果樹試報，A 15：83-91。

植原宣紘．1972．ブドウの台木を考える．山梨の園芸 $20(6): 25-31$.

植原宣絃。1984，台木の品種問題．p.123-130．宸業技術 大系。果樹編 2 (ブドウ)。㟵文協。東京。

Winkler, A. J., J. A. Cook, W. M. Kliewer and L. A. Lider. 1974. General viticulture. p. 686-692. Univ. of California Press, Berkeley.

Woodham, M. C., L. R. Krake and K. M. Cellier. 1983. The effect of grapevine leaf roll plus yellow speckle disease on annual growth, yield and qual. ity of grapes from Cabernet Franc under two pruning systems. Vitis $22: 13-19$.

山川祥秀・清水 均・櫛田忠衛. 1982. ブドウ“甲州にお ける味なし果と健全果の経時的成分変化について。 園学雑. $50: 454-460$. 